CLINICAL STUDY

\title{
The serum 25-hydroxyvitamin D response to vitamin D supplementation is related to genetic factors, BMI, and baseline levels
}

\author{
Allan Didriksen $^{1}$, Guri Grimnes ${ }^{1,2}$, Moira Strand Hutchinson ${ }^{1,2}$, Marie Kjærgaard ${ }^{1,2}$, Johan Svartberg ${ }^{1,2}$, \\ Ragnar M Joakimsen ${ }^{1,2}$ and Rolf Jorde Ji,2 $^{1,2}$ \\ ${ }^{1}$ Tromsø Endocrine Research Group, Department of Clinical Medicine, University of Tromsø, 9037 Tromsø, Norway and ${ }^{2}$ Division of Internal Medicine, \\ University Hospital of North Norway, 9038 Tromsø, Norway \\ (Correspondence should be addressed to A Didriksen who is now at Medical Department, University Hospital of North Norway, 9038 Tromse, Norway; \\ Email: allan.didriksen@unn.no)
}

\begin{abstract}
Objective: The serum 25-hydroxyvitamin D (25(OH)D) level is not only dependent on vitamin D intake and production in the skin but also dependent on genetic factors. Thus, in large genome-wide association studies, it has been shown that single nucleotide polymorphisms (SNPs) in the vitamin D binding protein (DBP), as well as in enzymes related to activation or degradation of vitamin D and its metabolites, are as important for the serum 25(OH)D level as the effect of season. How these SNPs affect the serum $25(\mathrm{OH}) \mathrm{D}$ response to vitamin D supplementation is uncertain.

Design and methods: Data were pooled from three randomized controlled trials where $40000 \mathrm{IU}$ vitamin D/week was given for 6 months. Serum 25(OH)D was measured before and at the end of the intervention, and the subjects were genotyped for SNPs related to the serum 25(OH)D level. Results: Baseline 25(OH)D levels were significantly related to SNPs in the DBP and CYP2R1 genes. Those with SNPs associated with the lowest baseline 25(OH)D levels also had the smallest increase (delta) after supplementation. Those with the lowest baseline serum 25(OH)D (without regard to genotypes) had the highest increase (delta) after supplementation. Subjects with high BMI had lowest baseline 25(OH)D levels and also the smallest increase (delta) after supplementation.

Conclusions: The serum 25(OH)D response to supplementation depends on genes, baseline level, and BMI. However, whether this is clinically important or not depends on the therapeutic window of vitamin $\mathrm{D}$, an issue that is still not settled.
\end{abstract}

European Journal of Endocrinology 169 559-567

\section{Introduction}

Vitamin D is produced in the skin after u.v. exposure or obtained through the diet, particularly oily fish, such as salmon and sardines (1). For vitamin D to become biologically active, it first has to be hydroxylated in the liver to 25-hydroxyvitamin D $(25(\mathrm{OH}) \mathrm{D})$, which is the metabolite used to evaluate a subject's vitamin D status, and then in the kidneys to 1,25-dihydroxyvitamin D $\left(1,25(\mathrm{OH})_{2} \mathrm{D}\right)(1)$. Accordingly, the serum $25(\mathrm{OH}) \mathrm{D}$ level is classically thought of as a result of intake of vitamin D and the sun-induced production of vitamin D in the skin.

In recent years, there has been a great focus on vitamin $\mathrm{D}$ and its possible extraskeletal effects $(2,3)$. The vitamin D receptor is located in numerous tissues (1), and associations between low serum 25(OH)D levels and risk of diseases like cardiovascular disease (4), diabetes (5), and cancer as well as mortality (6) have been reported. Although there is no consensus on what is the optimal serum $25(\mathrm{OH}) \mathrm{D}$ level, there is a general agreement that it should be at least $50 \mathrm{nmol} / \mathrm{l}(7,8,9)$. Accordingly, subjects with lower serum levels need vitamin $\mathrm{D}$ supplementation if the deficiency cannot be sufficiently corrected by changes in lifestyle with more outdoor activities or a vitamin $\mathrm{D}$ rich diet.

However, it has been shown that the serum 25(OH)D level is not only dependent on vitamin D intake and production in the skin but also dependent on genetic factors $(10,11,12)$. In large genome-wide association studies (GWAS), it has been shown that single nucleotide polymorphisms (SNPs) in the vitamin D binding protein (DBP), as well as in enzymes related to activation or degradation of vitamin $\mathrm{D}$ and its metabolites, are as important for the serum 25(OH)D level as the effect of season $(10,11,13,14)$. As these SNPs affect the serum 25(OH)D levels based on vitamin D produced in the skin or obtained from the diet, it is plausible that it should also affect the part of the $25(\mathrm{OH}) \mathrm{D}$ level that is produced from vitamin $\mathrm{D}$ taken as 
supplements. If so, it might be necessary to take genetic factors into account when recommending vitamin D supplementation. Obese subjects as a group have lower serum 25(OH)D levels than non-obese subjects, possibly due to a larger volume of distribution or degradation of vitamin $\mathrm{D}$ in adipose tissue $(15,16,17)$. Obesity may therefore also be a factor to consider when vitamin $\mathrm{D}$ supplementation is needed.

We have recently performed three intervention studies with high-dose vitamin D supplementation and also genotyped the subjects with regard to vitamin D SNPs. We therefore had the opportunity to test the influence of these SNPs as well as obesity on the serum $25(\mathrm{OH}) \mathrm{D}$ response to vitamin D supplementation.

\section{Subjects and methods}

\section{Study population}

In this study, we have pooled data from three intervention studies:

- The vitamin D and bone density study including postmenopausal women aged 50-80 years old, with a T-score in total hip or lumbar spine (L2-L4) $\leq-2.0$, and randomized to vitamin D $20000 \mathrm{IU}$ twice/week vs placebo for 1 year. In addition, all subjects were given daily supplements with $1 \mathrm{~g}$ calcium and $800 \mathrm{IU}$ vitamin D (ClinicalTrials.gov NTC00491920) (18).

- The vitamin D and insulin sensitivity study where subjects aged 30-75 years old with serum 25(OH)D $<50 \mathrm{nmol} / \mathrm{l}$ were included and randomized to vitamin D 20000 IU twice/week vs placebo for 6 months (ClinicalTrials.gov NCT00809744) (19).

- The vitamin D and depression study comprising subjects aged 30-75 years old, with serum 25(OH)D $\leq 55 \mathrm{nmol} / \mathrm{l}$ measured in the sixth Tromsø study, and randomized to vitamin D 20000 IU twice/week vs placebo for 6 months (ClinicalTrials.gov NCT00960232) (20).

\section{Measurements}

Height and weight were measured wearing light clothing and no shoes. BMI was calculated as weight divided by height squared. Serum PTH was measured as described previously (18). Serum 25(OH)D was measured with an LC-MSMS method (19). This assay has a within-day precision (coefficient of variation (CV)) $<3.2 \%$ and between-day precision $(\mathrm{CV})<8.8 \%$. The laboratory takes part in the external quality program DEQAS. All genotyping was performed by KBioscience (http://www.kbioscience.co.uk) using KASP SNP genotyping system. KASP is a competitive allele-specific PCR incorporating a FRET quencher cassette (21).

\section{Selection of SNPs for analysis}

Based on the reports from GWAS where several SNPs have been related to the serum $25(\mathrm{OH}) \mathrm{D}$ level $(10,11,12)$, we have in a previous study selected within each gene the one SNP with the highest difference in serum $25(\mathrm{OH}) \mathrm{D}$ between major and minor homozygotes: rs2282679 located at the DBP gene (DBP or GC); rs10741657 at the 25-hydroxylase gene (CYP2R1) involved in the conversion of vitamin D into $25(\mathrm{OH}) \mathrm{D}$; rs3829251 at the 7-dehydrocholesterol (7-DHC) reductase/NAD synthetase 1 gene (DHCR7/NADSYN1) responsible for the availability of $7-\mathrm{DHC}$ in the skin; and rs6013897 in the 24-hydroxylase gene (CYP24A1) involved in the degradation of 25(OH)D (21). In addition to these four SNPs, rs7041 and rs4588 (at the $D B P / G C$ gene) were included in the study as the effect of these two SNPs on the serum 25(OH)D response to vitamin D substitution has previously been published (22).

\section{Statistical analyses}

Distribution of the dependent variables serum 25(OH)D, delta 25(OH)D (serum 25(OH)D value at 6 months minus value at baseline), and BMI was evaluated for skewness and kurtosis and by visual inspection of histograms and found normal. Trends across the genotypes were evaluated with linear regression with age, gender, BMI, and season (summer/winter) as covariates where appropriate. The summer months were defined as May through September. Correlations were tested with Pearson's correlation coefficient $r$. The genotype frequencies were examined for compliance with Hardy-Weinberg equilibrium using $\chi^{2}$ analysis (23). Linkage disequilibrium (LD) between SNPs was evaluated with $r^{2}$ and Lewontin's D' statistics (24). Based on the $\beta$ coefficients from regression analyses with serum $25(\mathrm{OH}) \mathrm{D}$ as dependent variable, the risk alleles (the ones associated with low serum 25(OH)D levels) were weighted and a genetic risk score constructed $(10,21)$. A $P$ value $<0.05$ was considered statically significant. The data are presented as mean (s.D.) unless otherwise specified.

\section{Ethics}

The study was approved by the Regional Committee for Medical and Health Research Ethics. Only participants with valid written consent were included.

\section{Results}

rs4588 was in LD with rs2282679 $\left(r^{2}=0.98\right)$ and therefore excluded. The other SNPs were not in LD and were also in Hardy-Weinberg equilibrium ( $\chi^{2}$ testing $P>0.05)$. In the bone density, insulin sensitivity, and 
depression studies, 258, 91, and 219 subjects respectively completed the intervention and had complete data sets including genotyping for the three principal SNPs (see below). All but five subjects were of Northern European ancestry. In the bone density study and the insulin sensitivity study, $\sim 2 / 3$ of the subjects were included during the winter months, whereas in the depression study, all subjects were included during the winter. As expected, the serum 25(OH)D levels were higher in samples drawn during the summer than in the winter months in both the bone density and the insulin sensitivity studies (the two studies with inclusion throughout the year), but the mean difference was only $5 \mathrm{nmol} / \mathrm{l}$ (NS; Table 1).

There was no statistically significant relationship between the genotypes and age, BMI (except for BMI and rs3829251), and serum PTH in the three studies together, or between the genotypes and gender in the insulin sensitivity and depression studies. However, there was a significant effect of genotype for rs2282679, rs10741657, and rs7041 on serum $25(\mathrm{OH}) \mathrm{D}$ with a difference between the major and minor homozygote genotypes for rs2282679 of $15.4 \mathrm{nmol} / \mathrm{l}$, for $\mathrm{rs} 7041$ of $13.7 \mathrm{nmol} / \mathrm{l}$, and for rs10741657 of $5.8 \mathrm{nmol} / \mathrm{l}$. Similar results were seen when samples drawn during the winter or summer were analyzed separately. For the other SNPs, no such significant trend was seen. As expected, there was a clear difference between the genotype risk quartiles regarding serum $25(\mathrm{OH}) \mathrm{D}$ but not regarding age or BMI (Table 1). As previously published, the intake of vitamin D in the three studies was safe with no serious side effects, and in all three studies, there was a significant decrease in serum PTH after vitamin D supplementation $(18,19,20)$.

\section{Effect of genotype on serum 25(OH)D and PTH after vitamin $D$ supplementation}

In the bone density, insulin sensitivity, and depression studies, 127,47 , and 111 subjects respectively were randomized to vitamin $\mathrm{D}$ and these subjects were included in the following. In Table 2, the baseline, 6 months, and delta serum 25(OH)D levels (value at 6 months minus baseline) are shown for the three SNPs rs2282679, rs10741657, and rs7041 in relation to genotypes and also for the genotype score quartiles. For all these SNPs, the genotype with the highest baseline $25(\mathrm{OH}) \mathrm{D}$ level had the highest increase (delta) in serum $25(\mathrm{OH}) \mathrm{D}$ after vitamin D substitution. This was statistically significant for rs2282679 and rs1074657 with a difference in delta value between the genotype with the highest and lowest baseline 25(OH)D level of $15.5 \mathrm{nmol} / \mathrm{l}$ for $\mathrm{rs} 2282679$ and $15.9 \mathrm{nmol} / \mathrm{l}$ for rs10741657. Similar results were seen for the genotype score quartiles with a difference in delta values between quartile 1 (the quartile with the highest baseline serum $25(\mathrm{OH}) \mathrm{D})$ ) and quartile 4 of $21.4 \mathrm{nmol} / \mathrm{l}$ (Table 2).
There was for all genotypes a decrease in serum PTH after vitamin D supplementation. For rs2282679, the decrease in serum PTH was significantly related to genotype, with the major homozygote (which was associated with the highest increase (delta) in serum $25(\mathrm{OH}) \mathrm{D})$ having the largest decrease (delta) in serum PTH (Table 3).

\section{Effect of baseline level on serum 25(OH)D after vitamin $D$ supplementation}

There was a highly significant negative correlation between baseline serum 25(OH)D and increase (delta) in serum $25(\mathrm{OH}) \mathrm{D}(r=-0.25, P<0.001)$. In Table 4 , serum 25(OH)D after 6 months and delta 25(OH)D values are shown according to baseline $25(\mathrm{OH}) \mathrm{D}$ levels. Those with lowest baseline levels had the highest increase (delta) in serum 25(OH)D. However, the 6-month 25(OH)D values were still substantially lower in those starting $<40 \mathrm{nmol} / \mathrm{l}$ when compared with those starting $>69 \mathrm{nmol} / \mathrm{l}$. In trying to eliminate the effect of genetics on baseline values, we selected a group that was heterozygote for both rs2282679 and rs7041 (the two SNPs with the largest difference in $25(\mathrm{OH}) \mathrm{D}$ between the genotypes at baseline). In this cohort, the difference in delta values between those with low and high baseline $25(\mathrm{OH}) \mathrm{D}$ was even higher than when all genotypes were analyzed together, but the 6-month values were still lower in those with low baseline values (Table 4).

\section{Effect of BMI on serum 25(OH)D after vitamin $D$ supplementation}

At baseline, there was a negative association between serum 25(OH)D and BMI, which became statistically significant after 6 months with vitamin D supplementation $(P<0.001$; Table 4$)$. There was a highly significant negative correlation between increase (delta) in serum 25(OH)D after 6 months and baseline BMI $(r=-0.30, P<0.001)$ and a significant decrease in delta 25(OH)D with increasing BMI quartiles $(P<0.001)$ (Table 4). In the bone density study that lasted for 1 year, the difference in serum 25(OH)D between the BMI quartiles after vitamin D supplementation was statistically significant after 3 months and increased slightly thereafter till the end of the intervention (Table 5).

\section{Effects in the control groups}

In the placebo groups in the insulin sensitivity and depression studies, no significant changes were seen in serum 25(OH)D (data not shown). In the control group in the bone density study where 800 IU vitamin D were given per day, similar but smaller changes in serum $25(\mathrm{OH}) \mathrm{D}$ were seen as in those given $6800 \mathrm{IU} /$ day 


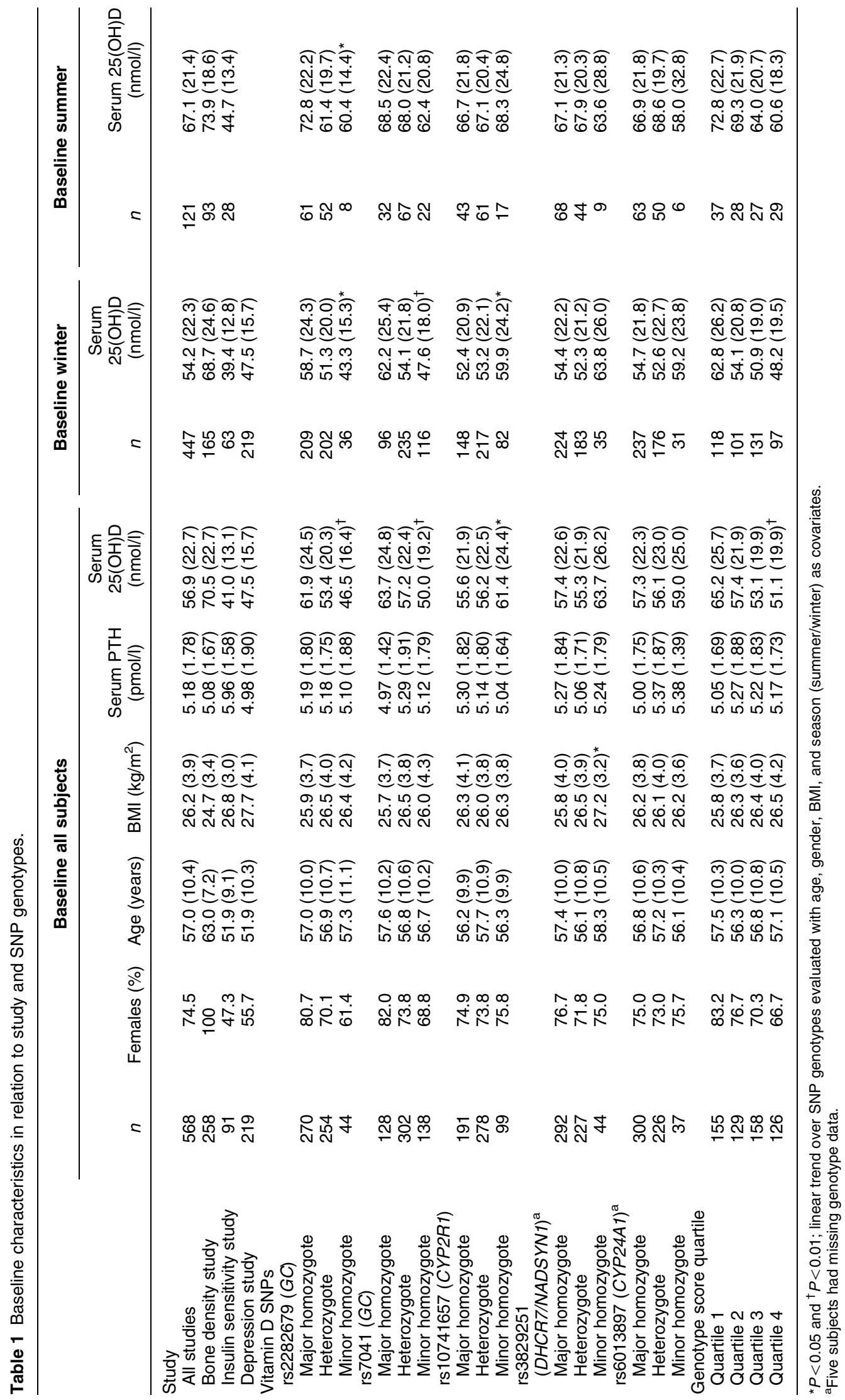


Table 2 Serum 25(OH)D at baseline, after 6 months, and delta values (value at 6 months minus baseline) in relation to vitamin D SNP genotypes in all subjects randomized to high-dose vitamin D supplementation.

\begin{tabular}{|c|c|c|c|c|}
\hline $\begin{array}{l}\text { Vitamin D SNP } \\
\text { genotypes }\end{array}$ & $n$ & $\begin{array}{l}\text { Baseline serum } \\
\text { 25(OH)D }(\mathrm{nmol} / \mathrm{l})\end{array}$ & $\begin{array}{l}\text { 6-month serum } \\
\text { 25(OH)D (nmol/l) }\end{array}$ & $\begin{array}{c}\text { Delta serum } \\
\text { 25(OH)D }(\mathrm{nmol} / \mathrm{l})\end{array}$ \\
\hline \multicolumn{5}{|l|}{ rs2282679 (GC) } \\
\hline Major homozygote & 138 & $61.3(23.5)$ & $169.9(36.1)$ & $108.6(32.1)$ \\
\hline Heterozygote & 131 & $53.7(22.1)$ & $152.2(28.3)$ & $98.4(29.3)$ \\
\hline Minor homozygote & 16 & $46.0(15.5)^{\dagger}$ & $139.2(23.9)^{\dagger}$ & $93.2(21.6)^{\star}$ \\
\hline \multicolumn{5}{|l|}{ rs7041 (GC) } \\
\hline Major homozygote & 70 & $62.5(22.7)$ & $169.9(35.2)$ & $107.5(29.3)$ \\
\hline Heterozygote & 155 & $57.6(24.1)$ & $158.7(32.2)$ & $101.2(31.7)$ \\
\hline Minor homozygote & 60 & $48.9(17.3)^{\dagger}$ & $151.9(32.7)^{\star}$ & $102.9(30.1)$ \\
\hline \multicolumn{5}{|l|}{ rs10741657 (CYP2R1) } \\
\hline Major homozygote & 96 & $55.9(23.3)$ & $152.8(31.6)$ & $96.9(31.1)$ \\
\hline Heterozygote & 136 & $55.0(20.5)$ & $158.7(31.2)$ & $103.7(28.9)$ \\
\hline Minor homozygote & 53 & $64.0(26.6)$ & $176.8(37.4)^{\dagger}$ & $112.8(33.0)^{\dagger}$ \\
\hline \multicolumn{5}{|c|}{ Genotype score quartile } \\
\hline Quartile 1 & 78 & $64.5(24.4)$ & $175.4(36.2)$ & 110.9 (33.2) \\
\hline Quartile 2 & 71 & $58.0(22.2)$ & $163.2(33.6)$ & $105.2(29.6)$ \\
\hline Quartile 3 & 80 & $52.4(20.2)$ & $155.6(28.2)$ & $103.1(27.1)$ \\
\hline Quartile 4 & 56 & $51.6(22.6)^{\dagger}$ & $141.1(25.6)^{\dagger}$ & $89.5(30.0)^{\dagger}$ \\
\hline
\end{tabular}

${ }^{*} P<0.05$ and ${ }^{\dagger} P<0.01$; linear trend over SNP genotypes evaluated with age, gender, BMI, and season (summer/winter) as covariates.

regarding the effects of genotypes and BMI (data not shown). When dividing this control group according to the baseline serum $25(\mathrm{OH}) \mathrm{D}$ levels, the differences in 25(OH)D almost disappeared after the 800 IU supplementation, probably because many of the subjects with high baseline values were taking vitamin D supplements that were stopped at inclusion in the study (Table 6).

\section{Discussion}

In this study, we have shown that the serum 25(OH)D levels are genetically determined and that the increase in serum $25(\mathrm{OH}) \mathrm{D}$ after vitamin D supplementation is related to genotype, baseline 25(OH)D level, and BMI. Furthermore, this was not restricted to a short 6-month intervention but persisted at least for 1 year as shown in the bone density study.

Our baseline results with a $15 \mathrm{nmol} / \mathrm{l}$ difference in serum 25(OH)D level between the major and minor homozygote genotypes for the DBP SNPs and a difference of $7.7 \mathrm{nmol} / \mathrm{l}$ for the CYP2R1 SNP is in agreement with what have previously been published by other groups $(10,11,12,25)$, as is the observation that the serum 25(OH)D levels are inversely related to BMI $(15,26)$.

The serum 25(OH)D levels measured by immunoassays as well as LC-MSMS methods reflect the total

Table 3 Serum PTH at baseline, after 6 months, and delta values (value at 6 months minus baseline) in relation to vitamin D SNP genotypes in all subjects randomized to high-dose vitamin D supplementation.

\begin{tabular}{|c|c|c|c|c|}
\hline $\begin{array}{l}\text { Vitamin D SNP geno- } \\
\text { types }\end{array}$ & $n$ & $\begin{array}{l}\text { Baseline serum PTH } \\
(\mathrm{pmol} / \mathrm{l})\end{array}$ & $\begin{array}{c}\text { 6-month serum PTH } \\
(\mathrm{pmol} / \mathrm{l})\end{array}$ & $\begin{array}{c}\text { Delta serum PTH } \\
(\mathrm{pmol} / \mathrm{l})\end{array}$ \\
\hline \multicolumn{5}{|l|}{ rs2282679 (GC) } \\
\hline Major homozygote & 138 & $5.25(1.61)$ & $4.00(1.35)$ & $-1.25(1.29)$ \\
\hline Heterozygote & 131 & $5.17(1.81)$ & $4.24(1.38)$ & $-0.94(1.31)$ \\
\hline Minor homozygote & 16 & $4.91(1.47)$ & $4.40(1.56)$ & $-0.51(1.48)^{*}$ \\
\hline \multicolumn{5}{|l|}{ rs7041 (GC) } \\
\hline Major homozygote & 70 & $5.10(1.49)$ & $3.87(1.32)$ & $-1.23(1.19)$ \\
\hline Heterozygote & 155 & $5.30(1.78)$ & $4.26(1.41)$ & $-1.04(1.30)$ \\
\hline Minor homozygote & 60 & $5.02(1.70)$ & $4.09(1.36)$ & $-0.94(1.50)$ \\
\hline \multicolumn{5}{|l|}{ rs10741657 (CYP2R1) } \\
\hline Major homozygote & 96 & $5.46(1.76)$ & $4.25(1.34)$ & $-1.21(1.39)$ \\
\hline Heterozygote & 136 & $5.05(1.68)$ & $4.07(1.40)$ & $-0.98(1.18)$ \\
\hline Minor homozygote & 53 & $5.08(1.60)$ & $4.06(1.40)$ & $-1.02(1.52)$ \\
\hline \multicolumn{5}{|l|}{ Genotype score quartile } \\
\hline Quartile 1 & 78 & $4.97(1.53)$ & $3.86(1.20)$ & $-1.11(1.33)$ \\
\hline Quartile 2 & 71 & $5.50(1.69)$ & $4.17(1.52)$ & $-1.34(1.28)$ \\
\hline Quartile 3 & 80 & $5.13(1.76)$ & $4.18(1.46)$ & $-0.95(1.12)$ \\
\hline Quartile 4 & 56 & $5.21(1.81)$ & $4.39(1.28)$ & $-0.81(1.57)$ \\
\hline
\end{tabular}

${ }^{*} P<0.05$; linear trend over SNP genotypes evaluated with age, gender, BMI, and season (summer/winter) as covariates. 
Table 4 Serum 25(OH)D at baseline, after 6 months, and delta values (value at 6 months minus baseline) in relation to baseline serum $25(\mathrm{OH}) \mathrm{D}$ level in all subjects and in subjects heterozygote for rs2282679 and rs7041 randomized to high-dose vitamin D supplementation.

\begin{tabular}{|c|c|c|c|c|}
\hline Subjects & $n$ & $\begin{array}{l}\text { Baseline serum } \\
\text { 25(OH)D (nmol/l) }\end{array}$ & $\begin{array}{l}\text { 6-month serum } \\
\text { 25(OH)D (nmol/l) }\end{array}$ & $\underset{(\mathrm{nmol} / \mathrm{l})}{\text { Delta serum } 25(\mathrm{OH}) \mathrm{D}}$ \\
\hline \multicolumn{5}{|c|}{ All subjects randomized to high-dose vitamin $D$} \\
\hline Baseline serum 25(OH)D <40 nmol// & 70 & $32.3(5.8)$ & $145.1(31.3)$ & $112.9(30.8)$ \\
\hline Baseline serum 25(OH)D 40-54 nmol/l & 82 & $46.8(4.6)$ & $151.8(28.3)$ & $105.1(28.5)$ \\
\hline Baseline serum 25(OH)D 55-69 nmol// & 60 & $61.7(4.3)$ & $160.0(30.8)$ & $98.3(30.5)$ \\
\hline Baseline serum 25(OH)D > $69 \mathrm{nmol} / \mathrm{l}$ & 73 & $88.2(16.5)$ & $183.5(31.0)^{*}$ & $95.4(31.3)^{*}$ \\
\hline \multicolumn{5}{|l|}{$\begin{array}{l}\text { Subjects heterozygote for rs2282679 and } \\
\text { rs7041 }\end{array}$} \\
\hline Baseline serum $25(\mathrm{OH}) \mathrm{D}<40 \mathrm{nmol} / \mathrm{l}$ & 25 & $31.6(6.9)$ & $143.7(27.9)$ & $112.0(26.3)$ \\
\hline Baseline serum 25(OH)D 40-54 nmol/l & 33 & $46.6(4.6)$ & $148.7(28.7)$ & $102.3(28.8)$ \\
\hline Baseline serum 25(OH)D 55-69 nmol/l & 24 & $60.6(3.7)$ & $153.5(24.5)$ & $92.9(24.2)$ \\
\hline Baseline serum 25(OH)D > $69 \mathrm{nmol} / \mathrm{l}$ & 21 & $90.5(19.8)$ & $169.8(28.2)$ & $79.3(34.4)^{*}$ \\
\hline \multicolumn{5}{|l|}{ All subjects randomized to vitamin D } \\
\hline Baseline $\mathrm{BMI}<22.5 \mathrm{~kg} / \mathrm{m}^{2}$ & 49 & $63.2(25.2)$ & $181.4(32.8)$ & $118.2(34.9)$ \\
\hline Baseline BMI $22.5-24.9 \mathrm{~kg} / \mathrm{m}^{2}$ & 68 & $59.7(26.1)$ & $169.2(34.2)$ & $109.4(31.2)$ \\
\hline Baseline BMI $25.0-27.4 \mathrm{~kg} / \mathrm{m}^{2}$ & 64 & $57.9(20.6)$ & $156.5(28.9)$ & $98.6(27.2)$ \\
\hline Baseline BMI $27.5-29.9 \mathrm{~kg} / \mathrm{m}^{2}$ & 56 & $52.0(20.3)$ & $148.9(29.5)$ & $96.9(29.0)$ \\
\hline Baseline $\mathrm{BMI}>29.9 \mathrm{~kg} / \mathrm{m}^{2}$ & 48 & $51.2(19.3)$ & $143.1(29.0)^{\star}$ & $91.9(25.2)^{\star}$ \\
\hline
\end{tabular}

${ }^{*} P<0.001$; linear trend over serum 25(OH)D and BMI groups with age, gender, and BMI (where appropriate) as covariates.

amount of 25(OH)D consisting of the DBP bound, the albumin bound, and the free $25(\mathrm{OH}) \mathrm{D}$ fraction. As the part bound to DBP is by far the largest (27), it is no surprise that polymorphisms in the $D B P$ could also affect the serum $25(\mathrm{OH}) \mathrm{D}$ level. Similarly, activating (or inactivating) polymorphisms in the CYP2R1 gene, which is involved in the hydroxylation of vitamin $\mathrm{D}$ to 25(OH)D, are also easy to envision as of importance for the $25(\mathrm{OH}) \mathrm{D}$ level. On the other hand, there is no consensus why obesity should affect the serum 25(OH)D level. This could be due to reduced intake of vitamin $\mathrm{D}$, reduced sun exposure, increased storage and/or sequestration of vitamin D in adipose tissue, or simply to an increased distribution volume for vitamin D $(16,28,29)$.

Although there are several reports on the effect of SNPs on basal serum 25(OH)D levels, the importance of these SNPs for the response to vitamin D substitution is sparse. Fu et al. (22) included 98 adults in a 1-year vitamin $\mathrm{D}$ intervention and related the increase in serum 25(OH)D to the rs4588 SNP genotypes (which in our study was in LD with rs2282679). They found the proportional (percentage) as well as absolute increase (delta) in mean 25(OH)D after vitamin D supplementation to be highest in those with the minor homozygote genotype, the group which also had the lowest baseline levels. In our study, the increase (delta) in serum $25(\mathrm{OH}) \mathrm{D}$ was highest in the $D B P$ genotypes with the highest baseline levels, but there were only four subjects with this genotype in the study by Fu et al. (22), which may explain the opposing results. In a recent study by Engelman et al. (30), the association between serum 25(OH)D levels and SNPs in the GC (DBP) and CYP2R1 genes were highly significant in samples drawn during the summer months and in subjects with high vitamin $\mathrm{D}$ intake (high exposure), but not in samples drawn during the winter and in subjects with low vitamin D intake (low exposure). This is in agreement with our results where the differences in serum $25(\mathrm{OH}) \mathrm{D}$ levels between the genotypes were most pronounced after 6 months with vitamin D supplementation.

It is unlikely that lifestyle factors (like diet or sun exposure) should be related to genotype, and the genetic effects on serum $25(\mathrm{OH}) \mathrm{D}$ are most likely due to differences in vitamin D metabolism. These metabolic

Table 5 Serum 25(OH)D at baseline and after 3, 6, 9, and 12 months in 127 postmenopausal women in the bone density study randomized to high-dose vitamin D supplementation.

\begin{tabular}{lccccrr}
\hline & & \multicolumn{3}{c}{ Serum 25(OH)D $(\mathrm{nmol} / \mathbf{l})$} \\
\cline { 6 - 8 } Baseline BMI $\left(\mathrm{kg} / \mathrm{m}^{2}\right)$ & $\boldsymbol{n}$ & Baseline & 3 months & 6 months & 9 months & 12 months \\
\hline$<22.5$ & 33 & $73.5(23.1)$ & $178.0(29.5)$ & $186.4(29.8)$ & $199.1(36.7)$ & $197.8(33.4)$ \\
$22.5-24.9$ & 36 & $73.8(25.3)$ & $173.6(30.0)$ & $184.9(32.7)$ & $194.5(33.3)$ & $192.0(37.4)$ \\
$25.0-27.4$ & 30 & $68.2(21.6)$ & $164.0(23.8)$ & $168.3(3.1)$ & $176.5(27.4)$ & $177.1(32.8)$ \\
$27.5-29.9$ & 16 & $69.1(23.6)$ & $155.8(20.8)$ & $164.2(34.2)$ & $174.7(22.5)$ & $174.9(28.0)$ \\
$>29.9$ & 12 & $62.5(20.2)$ & $161.7(22.0)^{\star}$ & $171.3(19.4)^{\star}$ & $181.0(28.7)^{\dagger}$ & $172.9(28.4)^{\dagger}$ \\
\hline
\end{tabular}

${ }^{*} P<0.05$ and ${ }^{\dagger} P<0.01$; linear trend over BMI groups with age as covariate. 
Table 6 Serum 25(OH)D at baseline, after 6 months, and delta values (value at 6 months minus baseline) in relation to baseline serum $25(\mathrm{OH}) \mathrm{D}$ level in the subjects in the bone density study that were given $800 \mathrm{IU}$ vitamin D/day.

\begin{tabular}{lcccc}
\hline Subjects & $\boldsymbol{n}$ & $\begin{array}{c}\text { Baseline serum } \\
\text { 25(OH)D (nmol/l) }\end{array}$ & $\begin{array}{c}\text { 6-month serum } \\
\text { 25(OH)D (nmol/l) }\end{array}$ & $\begin{array}{c}\text { Delta serum } \\
\text { 25(OH)D (nmol/l) }\end{array}$ \\
\hline $\begin{array}{l}\text { Baseline serum 25(OH)D } \\
\quad<40 \mathrm{nmol} / \mathrm{l}\end{array}$ & 10 & $33.2(5.1)$ & $91.2(11.5)$ & $58.0(13.5)$ \\
$\begin{array}{l}\text { Baseline serum 25(OH)D } \\
\quad 40-54 \mathrm{nmol} / \mathrm{l}\end{array}$ & 25 & $48.0(4.1)$ & $81.6(16.3)$ & $33.7(16.3)$ \\
$\begin{array}{l}\text { Baseline serum 25(OH)D } \\
\quad 55-69 \mathrm{nmol} / \mathrm{l}\end{array}$ & 32 & $62.6(4.0)$ & $81.2(15.8)$ & $18.6(15.7)$ \\
$\begin{array}{l}\text { Baseline serum 25(OH)D } \\
>69 \mathrm{nmol} / \mathrm{l}\end{array}$ & 64 & $88.8(14.7)$ & $103.7(27.4)$ & $14.9(25.1)^{*}$ \\
\hline
\end{tabular}

${ }^{\star} P<0.001 ;$ linear trend over serum 25(OH)D groups with age and BMI as covariates.

differences probably affect vitamin D coming from the skin and the ordinary diet in a similar way as vitamin D given as a supplement. Accordingly, subjects with a genetic potential for a high basal serum $25(\mathrm{OH}) \mathrm{D}$ level also have the greatest potential for increasing the serum 25(OH)D level after vitamin D supplementation. This is particularly so since the $25(\mathrm{OH}) \mathrm{D}$ level is mainly the result of vitamin $\mathrm{D}$ supply in contrast to the active form $1,25(\mathrm{OH})_{2} \mathrm{D}$, which is under strict regulation by PTH (1). This reasoning may not apply to differences in serum 25(OH)D due to the SNPs affecting the vitamin D production in the skin. However, polymorphisms in this system appears to affect the $25(\mathrm{OH}) \mathrm{D}$ level to a much lesser degree than the SNPs included in this study (10).

In addition to genotype, we confirmed previous observations that baseline serum $25(\mathrm{OH}) \mathrm{D}$ predicted the response to vitamin D supplementation $(31,32)$. Thus, those with lower baseline levels had the highest increase (delta). This relationship was to be expected as the main reason for low serum $25(\mathrm{OH}) \mathrm{D}$ levels is not genetic differences but differences in lifestyle (33). Therefore, those with low baseline levels have a greater potential for increase as the supplementation will make up for the effect of an unhealthy life style. This was further illustrated in the cohort where we tried to minimize the genetic effect by only including subjects heterozygote for two of the main SNPs affecting the serum 25(OH)D levels (rs2282679 and rs7041). And as expected, those with low baseline levels had a particularly high increase (delta) in serum 25(OH)D. However, it should be borne in mind that this observation could in part reflect a regression toward the mean.

And finally, we found BMI to affect the increase in serum $25(\mathrm{OH}) \mathrm{D}$ after supplementation as we and others have demonstrated before $(15,26)$. This was probably due to the same mechanism(s) causing low baseline $25(\mathrm{OH}) \mathrm{D}$ levels in obese subjects. Of particular note was that this effect of obesity did not diminish during a 12-month supplementation period, indicating that a fairly steady state with serum 25(OH)D levels lower than those in lean subjects is reached within 3-6 months of supplementation.
These findings implicate that in order to achieve a specific serum $25(\mathrm{OH}) \mathrm{D}$ target, the amount of vitamin $\mathrm{D}$ supplementation needed depends on genotype, basal level, as well as BMI. It is at present not certain what is the optimal 25(OH)D level nor how large the therapeutic window is. If this window is narrow, tailoring of supplementation will be of great importance and dose adjustments have to be made. However, it is more likely that the window is rather wide as it has been difficult to show a clinical effect of increasing the serum 25(OH)D level from $50-70 \mathrm{nmol} / \mathrm{l}$ to close to $150 \mathrm{nmol} / \mathrm{l}(18,19$, $20,34,35,36)$. Furthermore, it should be considered that what we are presently measuring is the total serum $25(\mathrm{OH}) \mathrm{D}$ level, and it is possible that the free or biologically active fraction is what should be considered as demonstrated by Powe et al. (37) regarding the relationship between $25(\mathrm{OH}) \mathrm{D}$ and bone mass density. Whether the free fraction also differs between the different SNPs in the same way as total $25(\mathrm{OH}) \mathrm{D}$ differs remains to be settled.

This study has some weaknesses. We pooled data from three different studies, and due to different study profiles, some heterogeneity would be expected, and only for the bone density study had we more than one measurement after starting the vitamin D supplementation. We did not have DBP measurements and it would have been of interest to know to what extent the SNPs correlate with this parameter, and thereby the effects on free/bioavailable serum $25(\mathrm{OH}) \mathrm{D}$. In this regard, it should also be noted that there was no relationship between the vitamin D SNPs and baseline serum PTH, which may indicate that the total serum $25(\mathrm{OH}) \mathrm{D}$ as measured in our study not necessarily reflects the biologically active part of $25(\mathrm{OH}) \mathrm{D}$ in serum. On the other hand, after vitamin D supplementation where the effect of genotype on serum 25(OH)D was more pronounced, there was at least for rs2282679 a relationship between genotype and decrease in serum PTH. Furthermore, the study was performed at a latitude of $69^{\circ}$ north and the results are therefore primarily applicable to populations with very low sun exposure. Our study also has strength in that we included a large group of subjects and the results were 
consistent and in accordance with present knowledge of vitamin D metabolism. It is also noteworthy that the high doses given by us appeared to be safe at least for a 6- to 12-month period.

In conclusion, we have found a strong association between genetic polymorphisms and basal levels of serum 25(OH)D and response to supplementation. However, the clinical importance of this observation remains to be determined.

\section{Declaration of interest}

The authors declare that there is no conflict of interest that could be perceived as prejudicing the impartiality of the research reported.

\section{Funding}

These studies were supported by grants from the Northern Norway Regional Health Authority, The University of Tromsø, The Norwegian Women Public Health Association in Troms, The Research Council of Norway, and the Norwegian Council of Cardiovascular Disease.

\section{Acknowledgements}

The superb assistance by the nurses at the Clinical Research Unit at the University Hospital of North Norway is gratefully acknowledged.

\section{References}

1 DeLuca HF. Overview of general physiologic features and functions of vitamin D. American Journal of Clinical Nutrition $2004 \mathbf{8 0}$ 1689S-1696S.

2 Wacker M \& Holick MF. Vitamin D - effects on skeletal and extraskeletal health and the need for supplementation. Nutrients 20135 111-148. (doi:10.3390/nu5010111)

3 Holick MF. Vitamin D deficiency. New England Journal of Medicine 2007357 266-281. (doi:10.1056/NEJMra070553)

4 Wang TJ, Pencina MJ, Booth SL, Jacques PF, Ingelsson E, Lanier K, Benjamin EJ, D'Agostino RB, Wolf M \& Vasan RS. Vitamin D deficiency and risk of cardiovascular disease. Circulation 2008117 503-511. (doi:10.1161/CIRCULATIONAHA.107.706127)

5 Grimnes G, Emaus N, Joakimsen RM, Figenschau Y, Jenssen T, Njolstad I, Schirmer H \& Jorde R. Baseline serum 25-hydroxyvitamin D concentrations in the Tromso study 1994-95 and risk of developing type 2 diabetes mellitus during 11 years of follow-up. Diabetic Medicine 201027 1107-1115. (doi:10.1111/j.14645491.2010.03092.x)

6 Hutchinson MS, Grimnes G, Joakimsen RM, Figenschau Y \& Jorde R. Low serum 25-hydroxyvitamin D levels are associated with increased all-cause mortality risk in a general population: the Tromso study. European Journal of Endocrinology 2010162 935-942. (doi:10.1530/EJE-09-1041)

7 Heaney RP. Health is better at serum 25(OH)D above $30 \mathrm{ng} / \mathrm{mL}$. Journal of Steroid Biochemistry and Molecular Biology 2013136 224-228. (doi:10.1016/j.jsbmb.2012.09.032)

8 Holick MF, Binkley NC, Bischoff-Ferrari HA, Gordon CM, Hanley DA, Heaney RP, Murad MH \& Weaver CM. Guidelines for preventing and treating vitamin D deficiency and insufficiency revisited. Journal of Clinical Endocrinology and Metabolism 201297 1153-1158. (doi:10.1210/jc.2011-2601)

9 Rosen CJ, Abrams SA, Aloia JF, Brannon PM, Clinton SK, DurazoArvizu RA, Gallagher JC, Gallo RL, Jones G, Kovacs CS et al. IOM committee members respond to Endocrine Society vitamin D guideline. Journal of Clinical Endocrinology and Metabolism 201297 1146-1152. (doi:10.1210/jc.2011-2218)
10 Wang TJ, Zhang F, Richards JB, Kestenbaum B, van Meurs JB, Berry D, Kiel DP, Streeten EA, Ohlsson C, Koller DL et al. Common genetic determinants of vitamin D insufficiency: a genome-wide association study. Lancet $2010 \quad 376$ 180-188. (doi:10.1016/ S0140-6736(10)60588-0)

11 Engelman CD, Meyers KJ, Ziegler JT, Taylor KD, Palmer ND, Haffner SM, Fingerlin TE, Wagenknecht LE, Rotter JI, Bowden DW et al. Genome-wide association study of vitamin D concentrations in Hispanic Americans: the IRAS family study. Journal of Steroid Biochemistry and Molecular Biology 2010122 186-192. (doi:10. 1016/j.jsbmb.2010.06.013)

12 Ahn J, Yu K, Stolzenberg-Solomon R, Simon KC, McCullough ML, Gallicchio L, Jacobs EJ, Ascherio A, Helzlsouer K, Jacobs KB et al. Genome-wide association study of circulating vitamin D levels. Human Molecular Genetics 201019 2739-2745. (doi:10.1093/ $\mathrm{hmg} / \mathrm{ddq} 155$ )

13 Gozdzik A, Zhu J, Wong BY, Fu L, Cole DE \& Parra EJ. Association of vitamin D binding protein (VDBP) polymorphisms and serum $25(\mathrm{OH}) \mathrm{D}$ concentrations in a sample of young Canadian adults of different ancestry. Journal of Steroid Biochemistry and Molecular Biology 2011127 405-412. (doi:10.1016/j.jsbmb.2011.05.009)

14 Perna L, Felix JF, Breitling LP, Haug U, Raum E, Burwinkel B, Schottker B \& Brenner H. Genetic variations in the vitamin D binding protein and season-specific levels of vitamin D among older adults. Epidemiology 201324 104-109. (doi:10.1097/EDE. Ob013e318276c4b0)

15 Jorde R, Sneve M, Emaus N, Figenschau Y \& Grimnes G. Crosssectional and longitudinal relation between serum 25-hydroxyvitamin D and body mass index: the Tromso study. European Journal of Nutrition 201049 401-407. (doi:10.1007/s00394010-0098-7)

16 Drincic AT, Armas LA, Van Diest EE \& Heaney RP. Volumetric dilution, rather than sequestration best explains the low vitamin D status of obesity. Obesity 201220 1444-1448. (doi:10.1038/oby. 2011.404)

17 Wortsman J, Matsuoka LY, Chen TC, Lu Z \& Holick MF. Decreased bioavailability of vitamin D in obesity. American Journal of Clinical Nutrition 200072 690-693.

18 Grimnes G, Joakimsen R, Figenschau Y, Torjesen PA, Almas B \& Jorde R. The effect of high-dose vitamin $\mathrm{D}$ on bone mineral density and bone turnover markers in postmenopausal women with low bone mass - a randomized controlled 1-year trial. Osteoporosis International 201223 201-211. (doi:10.1007/ s00198-011-1752-5)

19 Grimnes G, Figenschau Y, Almas B \& Jorde R. Vitamin D, insulin secretion, sensitivity, and lipids: results from a case-control study and a randomized controlled trial using hyperglycemic clamp technique. Diabetes 201160 2748-2757. (doi:10.2337/db11$0650)$

20 Kjaergaard M, Waterloo K, Wang CE, Almas B, Figenschau Y, Hutchinson MS, Svartberg J \& Jorde R. Effect of vitamin D supplement on depression scores in people with low levels of serum 25-hydroxyvitamin D: nested case-control study and randomised clinical trial. British Journal of Psychiatry 2012201 360-368. (doi:10.1192/bjp.bp.111.104349)

21 Jorde R, Schirmer H, Wilsgaard T, Joakimsen RM, Mathiesen EB, Njolstad I, Lochen ML, Figenschau Y, Berg JP, Svartberg J et al. Polymorphisms related to the serum 25-hydroxyvitamin D level and risk of myocardial infarction, diabetes, cancer and mortality. The Tromso study. PLoS ONE 20127 e37295. (doi:10.1371/ journal.pone.0037295)

22 Fu L, Yun F, Oczak M, Wong BY, Vieth R \& Cole DE. Common genetic variants of the vitamin $\mathrm{D}$ binding protein (DBP) predict differences in response of serum 25-hydroxyvitamin D [25(OH)D] to vitamin D supplementation. Clinical Biochemistry $2009 \mathbf{4 2}$ 1174-1177. (doi:10.1016/j.clinbiochem.2009.03.008)

23 Rodriguez S, Gaunt TR \& Day IN. Hardy-Weinberg equilibrium testing of biological ascertainment for Mendelian randomization studies. American Journal of Epidemiology 2009169 505-514. (doi:10.1093/aje/kwn359) 
24 Lewontin RC. The interaction of selection and linkage. I. General considerations; heterotic models. Genetics $19644949-67$.

25 Sinotte M, Diorio C, Berube S, Pollak M \& Brisson J. Genetic polymorphisms of the vitamin $\mathrm{D}$ binding protein and plasma concentrations of 25-hydroxyvitamin D in premenopausal women. American Journal of Clinical Nutrition $2009 \mathbf{8 9}$ 634-640. (doi:10.3945/ajcn.2008.26445)

26 Saliba W, Barnett-Griness O \& Rennert G. The relationship between obesity and the increase in serum 25(OH)D levels in response to vitamin D supplementation. Osteoporosis International 201324 1447-1454. (doi:10.1007/s00198-012-2129-0)

27 Yamamoto K, Sun WY, Ohta M, Hamada K, DeLuca HF \& Yamada S. Conformationally restricted analogs of $1 \alpha, 25$-dihydroxyvitamin D3 and its 20-epimer: compounds for study of the three-dimensional structure of vitamin D responsible for binding to the receptor. Journal of Medicinal Chemistry $1996 \mathbf{3 9}$ 2727-2737. (doi:10.1021/jm9600048)

28 Kamycheva E, Joakimsen RM \& Jorde R. Intakes of calcium and vitamin D predict body mass index in the population of Northern Norway. Journal of Nutrition 2003133 102-106.

29 Kamycheva E, Sundsfjord J \& Jorde R. Serum parathyroid hormone level is associated with body mass index. The 5th Tromso study. European Journal of Endocrinology $2004 \quad 151 \quad 167-172$. (doi:10.1530/eje.0.1510167)

30 Engelman CD, Meyers KJ, Iyengar SK, Liu Z, Karki CK, Igo RP Jr, Truitt B, Robinson J, Sarto GE, Wallace R et al. Vitamin D intake and season modify the effects of the GC and CYP2R1 genes on 25-hydroxyvitamin D concentrations. Journal of Nutrition 2013 143 17-26. (doi:10.3945/jn.112.169482)

31 Talwar SA, Aloia JF, Pollack S \& Yeh JK. Dose response to vitamin D supplementation among postmenopausal African American women. American Journal of Clinical Nutrition $2007 \mathbf{8 6}$ 1657-16662.
32 Holick MF \& Chen TC. Vitamin D deficiency: a worldwide problem with health consequences. American Journal of Clinical Nutrition 200887 1080S-1086S.

33 Berry D \& Hypponen E. Determinants of vitamin D status: focus on genetic variations. Current Opinion in Nephrology and Hypertension 201120 331-336. (doi:10.1097/MNH.Ob013e328346d6ba)

34 Jorde R, Sneve M, Torjesen P \& Figenschau Y. No improvement in cardiovascular risk factors in overweight and obese subjects after supplementation with vitamin D3 for 1 year. Journal of Internal Medicine 2010267 462-472. (doi:10.1111/j.1365-2796.2009. 02181.x)

35 Jorde R, Sneve M, Torjesen PA, Figenschau Y, Goransson LG \& Omdal R. No effect of supplementation with cholecalciferol on cytokines and markers of inflammation in overweight and obese subjects. Cytokine 201050 175-180. (doi:10.1016/j.cyto.2009. 12.006)

36 Jorde R, Sneve M, Torjesen PA, Figenschau Y, Hansen JB \& Grimnes G. No significant effect on bone mineral density by high doses of vitamin D3 given to overweight subjects for one year. Nutrition Journal 20109 1. (doi:10.1186/1475-2891-9-1)

37 Powe CE, Ricciardi C, Berg AH, Erdenesanaa D, Collerone G, Ankers E, Wenger J, Karumanchi SA, Thadhani R \& Bhan I. Vitamin D-binding protein modifies the vitamin D-bone mineral density relationship. Journal of Bone and Mineral Research 201126 1609-1616. (doi:10.1002/jbmr.387)

Received 22 March 2013

Revised version received 19 July 2013

Accepted 9 August 2013 